\title{
Differential roles of NHERF1, NHERF2, and PDZK1 in regulating CFTR-mediated intestinal anion secretion in mice
}

\author{
Anurag Kumar Singh, ${ }^{1}$ Brigitte Riederer, ${ }^{1}$ Anja Krabbenhöft, ${ }^{1}$ Brigitte Rausch, ${ }^{1}$ Janina Bonhagen, ${ }^{1}$ \\ Ulrich Lehmann, ${ }^{2}$ Hugo R. de Jonge, ${ }^{3}$ Mark Donowitz, ${ }^{4}$ Chris Yun, ${ }^{5}$ Edward J. Weinman, ${ }^{6}$ \\ Olivier Kocher, ${ }^{7}$ Boris M. Hogema, ${ }^{3}$ and Ursula Seidler ${ }^{1}$
}

\begin{abstract}
'Department of Gastroenterology, Hepatology, and Endocrinology, and 2Department of Pathology, Hannover Medical School, Hannover, Germany. ${ }^{3}$ Department of Biochemistry, Erasmus University Medical Center, Rotterdam, The Netherlands. ${ }^{4}$ Department of Medicine and Department of Physiology, Johns Hopkins University School of Medicine, Baltimore, Maryland, USA. ${ }^{5}$ Department of Medicine, Emory University School of Medicine, Atlanta, Georgia, USA. ${ }^{6}$ Department of Medicine, University of Maryland School of Medicine, Baltimore, Maryland, USA. ${ }^{7}$ Department of Pathology, Beth Israel Deaconess Medical Center, Harvard Medical School, Boston, Massachusetts, USA.
\end{abstract}

\begin{abstract}
The epithelial anion channel CFTR interacts with multiple PDZ domain-containing proteins. Heterologous expression studies have demonstrated that the $\mathrm{Na}^{+} / \mathrm{H}^{+}$exchanger regulatory factors, NHERF1, NHERF2, and PDZK1 (NHERF3), modulate CFTR membrane retention, conductivity, and interactions with other transporters. To study their biological roles in vivo, we investigated CFTR-dependent duodenal $\mathrm{HCO}_{3}{ }^{-}$secretion in mouse models of Nherf1, Nherf2, and Pdzk1 loss of function. We found that Nherf1 ablation strongly reduced basal as well as forskolin-stimulated (FSK-stimulated) $\mathrm{HCO}_{3}{ }^{-}$secretory rates and blocked $\beta_{2}$-adrenergic receptor $\left(\beta_{2}\right.$-AR) stimulation. Conversely, Nherf $2^{-/-}$mice displayed augmented FSK-stimulated $\mathrm{HCO}_{3}{ }^{-}$secretion. Furthermore, although lysophosphatidic acid (LPA) inhibited FSK-stimulated $\mathrm{HCO}_{3}{ }^{-}$secretion in WT mice, this effect was lost in Nherf2 $2^{-/-}$mice. Pdzk1 ablation reduced basal, but not FSK-stimulated, $\mathrm{HCO}_{3}{ }^{-}$secretion. In addition, laser microdissection and quantitative PCR revealed that the $\beta_{2}$-AR and the type 2 LPA receptor were expressed together with CFTR in duodenal crypts and that colocalization of the $\beta_{2}$-AR and CFTR was reduced in the $\mathrm{Nherf1}^{-/-}$mice. These data suggest that the NHERF proteins differentially modulate duodenal $\mathrm{HCO}_{3}{ }^{-}$secretion: while NHERF1 is an obligatory linker for $\beta_{2}$-AR stimulation of CFTR, NHERF2 confers inhibitory signals by coupling the LPA receptor to CFTR.
\end{abstract}

\section{Introduction}

The epithelial anion channel CFTR has been recognized as a hub protein, connecting to many other proteins and thus able to form protein-protein networks and affecting an astonishingly large number of cellular functions in addition to its ability to transport $\mathrm{Cl}^{-}$and $\mathrm{HCO}_{3}^{-}$(1-4). Important for this property as a connector hub is its C-terminal postsynaptic density protein PSD95-Drosopbila homo$\log$ discs-large and tight junction protein $\mathrm{ZO}-1$-binding (PDZbinding) motif, which enables CFTR to bind to the PDZ domains of a variety of $\mathrm{PDZ}$ adapter proteins, including $\mathrm{Na}^{+} / \mathrm{H}^{+}$exchanger regulatory factor 1 (NHERF1; also known as NHERF, EBP50, or SLC9A3R1), NHE3 kinase A regulatory protein (NHERF2; also known as E3KARP or SLC9A3R2), and PDZ domain-containing protein in kidney 1 (PDZK1; also known as CAP70 or NHERF3) of the NHERF family of PDZ adapters $(2,3)$. Heterologous expression studies have provided evidence for the importance of these interactions for CFTR trafficking and membrane retention (5-7), dimerization $(8,9)$, membrane mobility $(10,11)$, interaction with other transporters (12-14), and, perhaps most interestingly, the forma-

Conflict of interest: The authors have declared that no conflict of interest exists. Nonstandard abbreviations used: $\beta_{2}-A R, \beta_{2}$-adrenergic receptor; BBM, brush border membrane; FSK, forskolin; Isc, short circuit current; LPA, lysophosphatidic acid; $\mathrm{LPA}_{2} \mathrm{R}$, type $2 \mathrm{LPA}$ receptor; $\mathrm{NHERF} 1, \mathrm{Na}^{+} / \mathrm{H}^{+}$exchanger regulatory factor 1 ; NHERF2, NHE3 kinase A regulatory protein; PDZ, postsynaptic density protein PSD95-Drosopbila homolog discs-large and tight junction protein ZO-1; PDZK1, PDZ domain-containing protein in kidney 1.

Citation for this article: J. Clin. Invest. 119:540-550 (2009). doi:10.1172/JCI35541. tion of multiprotein signaling complexes in which receptor-mediated signals are directly conveyed to the transporter $(15,16)$. Highly exciting to basic scientists as well as physicians treating CF patients were the recent reports that in a cell line expressing a CFTR trafficking mutant ( $\triangle \mathrm{F} 508)$, either overexpression of NHERF1 (17) or siRNA-mediated knockdown of CAL (18), a Golgi-located PDZ protein that targets CFTR to the lysosomal pathway, resulted in redistribution of the mutated CFTR to the plasma membrane and an increased $\mathrm{Cl}^{-}$efflux. These and other findings make NHERF- and other PDZ domain-mediated protein-protein interactions both a desirable drug target and a likely point of origin for pathophysiological changes $(19,20)$. On the other hand, the high sequence homology among the NHERF proteins (21-25), their overlapping tissue expression (26-28), a seemingly similar effect on CFTR function in heterologous expression systems (3), and the relative health of NHERF-deficient mice $(12,29,30)$ have raised questions about redundancy and the importance of these proteins' role in native tissue and in the living organism.

Broere et al. have recently reported a decreased cAMP-activated short circuit current $\left(\mathrm{I}_{\mathrm{sc}}\right)$ and $\mathrm{HCO}_{3}{ }^{-}$secretory rate in $\mathrm{Nherf1}^{-/-}$mouse isolated small intestinal mucosa and a less intense CFTR staining pattern in the brush border membrane (BBM) of jejunal crypt cells, whereas no change in these parameters was seen in Nherf $2^{-1-}$ mouse small intestine (31). Hillesheim et al. observed a mild decrease in forskolin-stimulated (FSK-stimulated) $\mathrm{I}_{\mathrm{sc}}$ and $\mathrm{HCO}_{3}{ }^{-}$secretion in $P d z k 1^{-/-}$mouse small intestine (32). To our knowledge, no in vivo studies have previously been performed in these mice. 

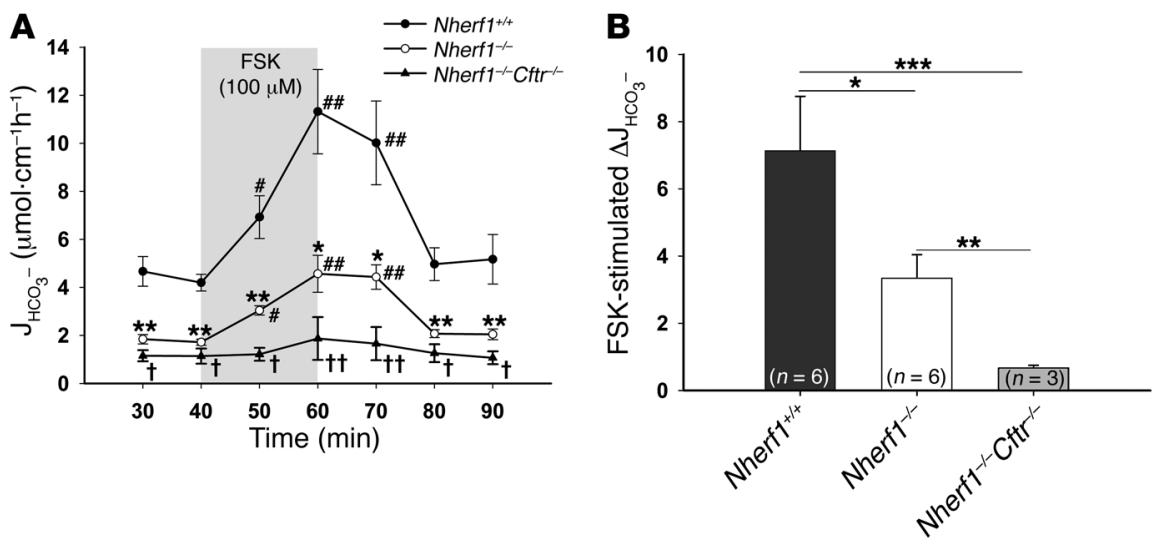

Figure 1

Basal and FSK-stimulated $\mathrm{HCO}_{3}{ }^{-}$secretion in $\mathrm{Nherf1}^{-1-}$, Nherf1 ${ }^{-1-} \mathrm{Cftr}^{-1}$, and WT murine duodenum in vivo. (A) Duodenal $\mathrm{HCO}_{3}{ }^{-}$secretion was measured in anesthetized $\mathrm{Nherf1}^{-1-}$, $\mathrm{Nherf1}^{-1-} \mathrm{Cftr}^{-1}$, and WT littermates in the basal state, and during and after 20 min luminal perfusion with $10^{-4} \mathrm{M} \mathrm{FSK}$. Basal as well as FSK-stimulated duodenal $\mathrm{HCO}_{3}{ }^{-}$secretion was dramatically reduced in the Nherf1-1and Nherf1 ${ }^{-1-C f t r}{ }^{-1}$ mice compared with WT littermates ( $n=6$ pairs of KO and WT mice, $\left.P<0.001\right)$. The 20-min application time is denoted by shading. ${ }^{\star} P<0.01$, ${ }^{\star \star} P<0.001,{ }^{\star \star \star} P<0.0001$ versus WT; ${ }^{\prime} P<0.01,{ }^{\# \#} P<0.001$ versus basal value; ${ }^{\dagger} P<0.01,{ }^{t \dagger} P<0.001$ versus $N$ herf $1^{-1-}$. (B) The net peak FSK- stimulated $\mathrm{HCO}_{3}{ }^{-}$secretory rate was significantly lower in $\mathrm{Nherf1}^{-/-}$and $\mathrm{Nherf1}^{-/-} \mathrm{Cftr}^{-1}$ mice than in WT littermates. The net peak was calculated for each experiment in this and subsequent experiments by taking the peak value and subtracting the average of the 2 basal values before the application of $10^{-4}$ M FSK. ${ }^{*} P<0.01$; ${ }^{* \star} P<0.001$; ${ }^{* \star \star} P<0.0001$.

CFTR is highly expressed in murine duodenum and is essential for the $\mathrm{HCO}_{3}^{-}$secretion in this tissue (33-36). Measuring duodenal $\mathrm{HCO}_{3}{ }^{-}$secretion is one of the few parameters to assess CFTR function quantitatively in a living organism. To learn more about the biological significance of the NHERF proteins in CFTR regulation, we measured basal and FSK-stimulated duodenal $\mathrm{HCO}_{3}{ }^{-}$secretion in anesthetized mice lacking one or more of the NHERF proteins. The importance of NHERF1 in mediating receptor-dependent activation and of NHERF2 in receptor-dependent inhibition of CFTR was studied, and colocalization of the receptors, the NHERF proteins, and CFTR was demonstrated in the apical membranes of crypt duodenocytes. In this way, for the first time to our knowledge, the concept of $G$ protein-coupled receptor signaling to CFTR via a specific NHERF protein was validated in the living animal.

\section{Results}

Reduced basal and FSK-stimulated duodenal $\mathrm{HCO}_{3}{ }^{-}$secretory rates in Nherf $1^{-/}$mice in vivo. The basal $\mathrm{HCO}_{3}^{-}$secretory rate in the duodenum of anesthetized Nherf1 $1^{-/-}$as well as Nherf $1^{-/-} \mathrm{Cftr} r^{-/}$double-deficient mice was dramatically reduced compared with WT littermates, and the response to a maximally stimulatory concentration of FSK was strongly reduced, but still significant, in the Nherf1 $1^{-/-}$duodenum and virtually abolished in the Nherf1 $1^{-/-}$ $\mathrm{Cftr}^{-/-}$mice (Figure 1, A and B). This suggests that the presence of NHERF1 is essential for maximal stimulation of CFTR by an increase in intracellular cAMP in the murine duodenum. To investigate whether the NHERF1-dependent reduction of duodenal $\mathrm{HCO}_{3}{ }^{-}$secretion was caused by reduced CFTR activation, we next studied $\mathrm{Nherf1}^{-1-} \mathrm{Cftr}^{-1-}$ mice, which displayed no significant stimulation of duodenal $\mathrm{HCO}_{3}{ }^{-}$secretion upon FSK treatment (Figure 1, A and B). These results were similar to those in $\mathrm{Cftr}^{-1}$ mice (data not shown).
NHERF1 is essential for $\beta_{2}$-adrenergic stimulation of duodenal $\mathrm{HCO}_{3}^{-}$secretion. One of the most astonishing results of the previously described experiments was the strong reduction in the basal $\mathrm{HCO}_{3}{ }^{-}$ secretory rate in the absence of NHERF1. These changes were not observed in isolated epithelium (31). We therefore investigated whether a tonic stimulation of CFTR that only occurs in vivo might explain these effects, possibly via NHERF1-mediated formation of a CFTRreceptor signaling complex. Of course, multiple possibilities for such endogenous stimulators are feasible. The only NHERF1-mediated CFTR-receptor interaction with a stimulatory action that has been studied in molecular detail in a cell line is the formation of a complex containing the $\beta_{2}$-adrenergic receptor $\left(\beta_{2}-\mathrm{AR}\right.$, encoded by Adrb2), NHERF1, PKA, and CFTR (16). Whether $\beta_{2}$-ARs are present in intestinal epithelium and whether their activation stimulates duodenal $\mathrm{HCO}_{3}{ }^{-}$secretion is presently unknown. We therefore amplified and sequenced an Adrb2 transcript from isolated murine duodenal epithelium. Interestingly, the mRNA expression of Adrb2 was significantly upregulated in the duodenum, but not in the lungs, of $\mathrm{Nherf1}^{-/-}$mice (Figure 2A).

We next investigated whether the $\beta_{2}$-AR is colocalized with CFTR and NHERF1 in the apical membrane of duodenal enterocytes. To this end, we isolated BBM from murine duodenum and performed Western blot analysis with antibodies against CFTR, $\boldsymbol{\beta}_{2}$-AR (Figure 2B), and NHERF1 (data not shown), as has been published before (31). A band in the appropriate size for CFTR, $\beta_{2}$-AR, and NHERF1 was clearly enriched in the respective BBM fractions. The specificity of the antibody was checked either by blocking peptide (for $\beta_{2}$-AR) or by using gene-deficient mice (for CFTR).

Immunohistochemistry was used next to confirm these results and to more precisely define the colocalization of CFTR and the $\beta_{2}$-AR. Anti-CFTR antibody localized CFTR to the apical membranes in the duodenocytes predominantly in the cryptal region and Brunner's glands, as described previously (37). Anti- $\boldsymbol{\beta}_{2}$-AR antibody localized the $\beta_{2}$-AR to the apical membrane of the villi as well as crypt duodenocytes and the epithelial lining of the Brunner's glands, and there was staining in the muscle layer as well. The apical localization of NHERF1 in the crypt and villous region has been published previously (31) and was identical in the murine duodenum (data not shown). The yellow staining in Figure $3 \mathrm{~B}$ indicates colocalization of CFTR and $\beta_{2}$-AR in the WT duodenum. In the absence of Nherf1, the staining appeared more diffuse, although a substantial part of both proteins was still localized in the BBM.

To test whether one component of the basal $\mathrm{HCO}_{3}{ }^{-}$secretion is NHERF1 dependent, we applied the specific $\beta_{2}$-AR antagonist ICI-118551. In WT mice, but not in $\mathrm{Nherf1}^{-/-}$mice, $100 \mu \mathrm{M}$ ICI118551 significantly inhibited basal $\mathrm{HCO}_{3}{ }^{-}$secretion (Figure 4A). This is indicative of an involvement of $\beta_{2}$-AR activation in the basal $\mathrm{HCO}_{3}{ }^{-}$secretory tone in anesthetized mice and suggests that this 
A
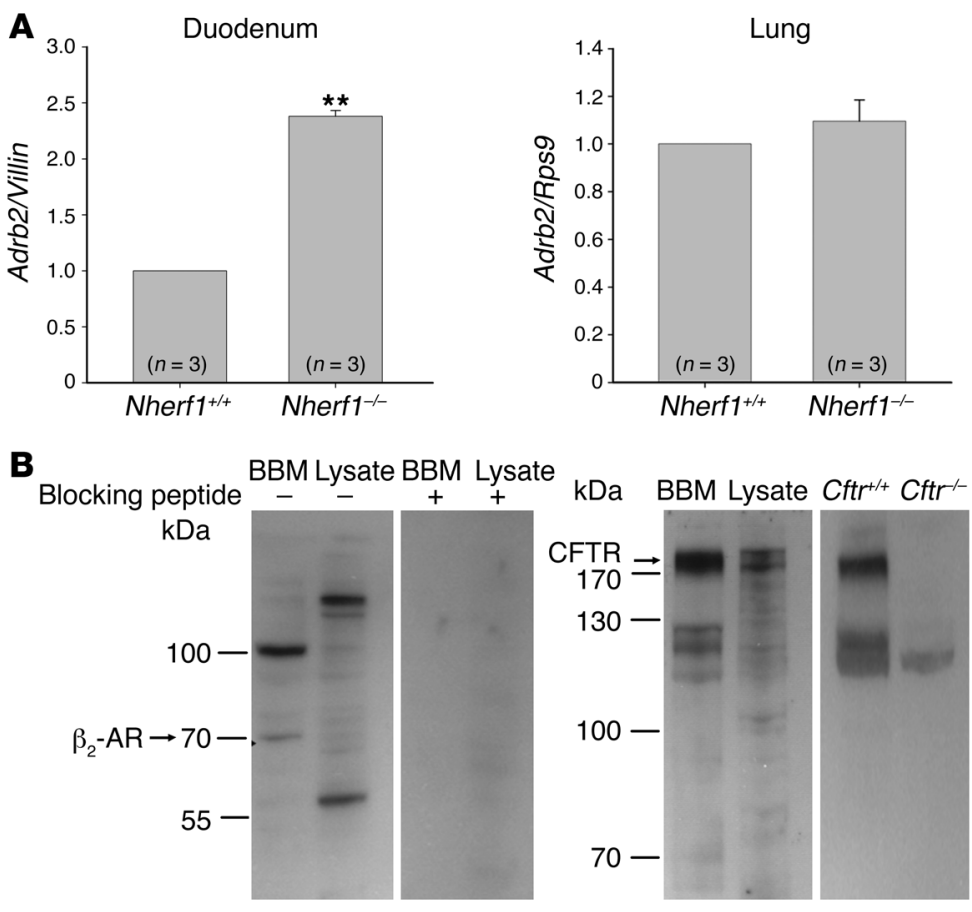

\section{Figure 2}

Duodenal epithelial Adrb2 mRNA expression and apical membrane localization of CFTR and the $\beta_{2}$-AR. (A) mRNA encoding the $\beta_{2}$-AR was expressed in murine duodenal epithelium and was significantly higher in the duodenum of $\mathrm{Nherf1}^{-1-}$ than in WT mice. Conversely, no difference in Adrb2 mRNA expression level was observed in the lungs of $\mathrm{Nherf1}^{-1-}$ mice. Experiments were performed in triplicate for each RNA extract from 3 pairs of mice. ${ }^{* *} P<0.01$ versus WT. (B) Western blot analysis of CFTR and the $\beta_{2}-A R$ in the BBM fraction and total cell lysate from duodenal epithelial scrapings showed that both proteins were enriched in the BBM. Both bands were blocked in the $\beta_{2}$-AR Western blot using the blocking peptide, showing the specificity of the antibody. The higher-molecular weight band is likely a heterodimeric form of the receptor, as has been reported (62). The specificity of the CFTR band was checked using protein lysate and BBM preparation from $\mathrm{Cftr}^{-1}$ mice. The expected molecular weight of the protein is indicated. stimulation is NHERF1 dependent. To further study this hypothesis, we applied the selective $\beta_{2}$-AR agonist clenbuterol to the duodenal lumen of Nherf1 $1^{-/}$and WT mice and found that $50 \mu \mathrm{M}$ clenbuterol in the luminal perfusate caused a significant stimulation of duodenal $\mathrm{HCO}_{3}{ }^{-}$secretion in the WT mice that was completely absent in the Nherf1 $1^{-/-}$mice (Figure 4B). The total lack of response to clenbuterol in the absence of NHERF1 demonstrates the necessity of this interaction for the $\beta_{2}$-AR-mediated stimulation of CFTR and strengthens the concept of NHERF1-mediated complex formation between the $\beta_{2}$-AR and CFTR. To test whether this effect is specific for Nherf1 ablation, we repeated the experiments in Nherf $2^{-/-}$and $P d z k 1^{-/-}$mice. Basal $\mathrm{HCO}_{3}{ }^{-}$secretory rates were different in the Nherf 2 and Pdzk1 WT and KO mice, as discussed below, but the effects of both ICI-118551 and clenbuterol were preserved (Figure 4C).

FSK-stimulated duodenal $\mathrm{HCO}_{3}^{-}$secretion is increased in Nherf2--/mice. Nherf $2^{-/}$mice did not display significant differences in basal $\mathrm{HCO}_{3}{ }^{-}$secretion compared with WT controls, but had a significantly stronger secretory response to $10^{-4} \mathrm{M}$ luminal FSK (Figure 5 , A and B). This was highly surprising, because it was not previously observed in isolated duodenal mucosa (31), and any potential effect of NHERF2 on FSK-mediated $\mathrm{HCO}_{3}{ }^{-}$secretion was expected to be stimulatory instead of inhibitory based on experiments in airway cell lines (38) as well as in vitro studies (39). However, the results clearly suggested an inhibitory effect of NHERF2 on intestinal CFTR activity. We then asked 2 questions: (a) Can the reduced in vivo CFTR activity in $\mathrm{Nherf1}^{-/-}$duodenum be rescued by additional KO of Nherf2?; and (b) Can we find evidence for NHERF2-mediated inhibitory receptor-CFTR signaling complex formation in murine duodenum in vivo?

To answer the first question, Nherf1 $1^{-/}$, Nherf $2^{-/-}$, Nherf $1^{+/+}$ Nherf $2^{+/+}$, and Nherf1 $1^{-/-}$Nherf $2^{-/-}$mice were bred from the same founders, and the basal as well as FSK-stimulated $\mathrm{HCO}_{3}{ }^{-}$secretory rates were measured in all $3 \mathrm{KO}$ mouse lines as well as the respective WT mice (Figure 5, $\mathrm{C}$ and $\mathrm{D}$ ). The additional deletion of Nherf2 significantly increased the basal $\mathrm{HCO}_{3}{ }^{-}$secretory rate observed in Nherf1 $1^{-/-}$mice (Figure 5C), suggesting that the inhibitory NHERF2-mediated event did not require NHERF1 and that it was active under basal conditions. The FSK-stimulated maximal secretory rate, on the other hand, was only mildly increased in Nherf $1^{-/-}$Nherf $2^{-/-}$mice compared with $N$ herf1 $1^{-/-}$mice, demonstrating the absolute requirement of NHERF1 for maximal duodenal CFTR activation in vivo (Figure 5D). The experiments also demonstrate that NHERF1 and NHERF2 are likely to act independently from each other on CFTR.

NHERF2 is essential for lysophosphatidic acid inhibition of duodenal $\mathrm{HCO}_{3}{ }^{-}$secretion. To answer the second question, we searched for potential inhibitory effects of NHERF2 in the literature. A recent report provided evidence for an inhibitory effect of lysophosphatidic acid (LPA) on ${ }^{36} \mathrm{Cl}^{-}$efflux in a CFTR-expressing cell line, as well as on $\mathrm{I}_{\mathrm{sc}}$ in intestinal tissue (15). In addition, the type $2 \mathrm{LPA}$ receptor $\left(\mathrm{LPA}_{2} \mathrm{R}\right.$, encoded by $L$ par 2$)$, which was shown to mediate this inhibitory effect, was shown to interact with NHERF2 (15), suggesting that NHERF2 mediated the link between CFTR and the $\mathrm{LPA}_{2} \mathrm{R}$ in the BBM. We sought to test this hypothesis in intact murine duodenum in vivo by searching for $\mathrm{LPA}_{2} \mathrm{R}, \mathrm{CFTR}$, and NHERF2 colocalization in the murine duodenum using 2 different approaches. First, we performed Western blot analysis of isolated duodenal BBM and found $\mathrm{LPA}_{2} \mathrm{R}$ as well as NHERF2 to be enriched in the apical membrane (Figure 6A). Immunohistochemical analysis was not possible because no specific (i.e. $\mathrm{LPA}_{2} \mathrm{R}$ peptide-blocked) staining was detected. We therefore laser dissected the epithelial cells lining the crypt region and those lining the upper villous region (not the tip, but the upper half), and performed quantitative PCR to check for expression of $\mathrm{LPA}_{2} \mathrm{R}, \mathrm{NHERF} 2$, and CFTR. Interestingly, all 3 mentioned mRNAs were strongly enriched in the crypt region (Figure 6, B-D), whereas proteins typically predominant in the 
A
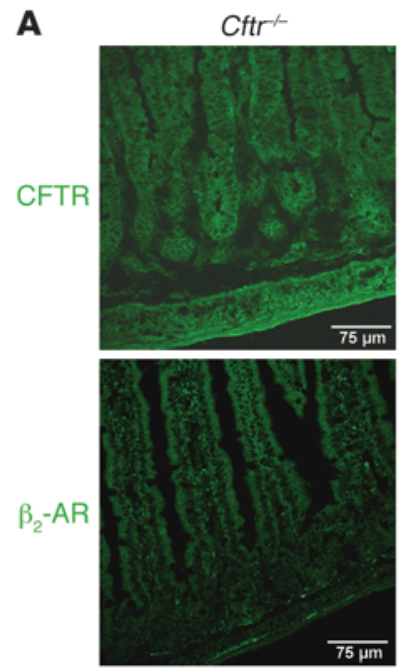

Blocking peptide

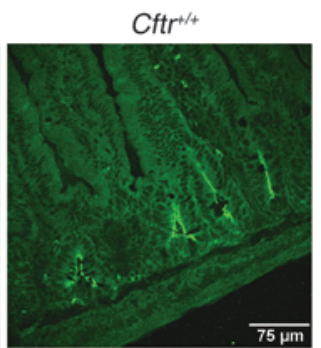

B

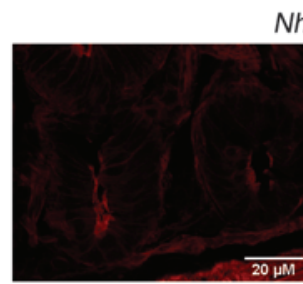

Nherf1 $1^{+/+}$

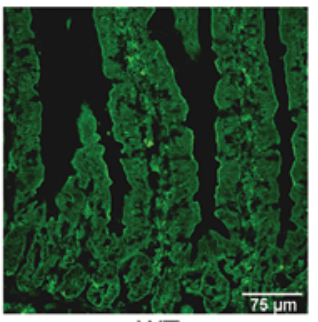

WT
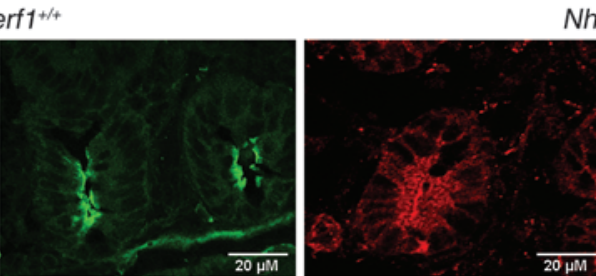

Nherf1 $1^{--}$
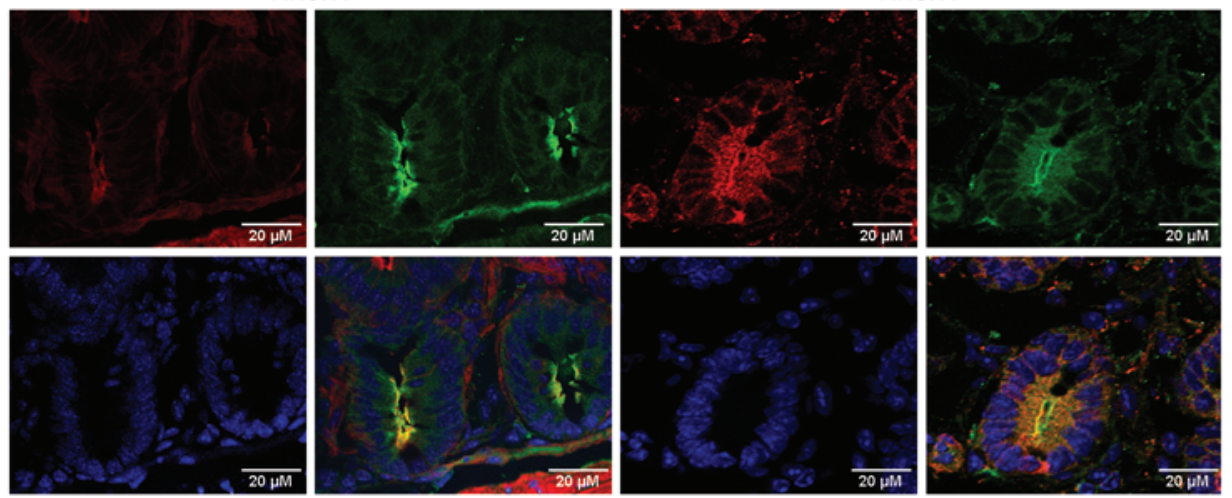

$\beta_{2}$-AR/CFTR/DAPI

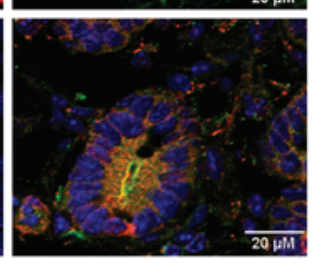

Figure 3

Colocalization of CFTR and $\beta_{2}$-AR in the apical membrane of duodenal crypts. (A) Top: Immunohistochemical staining with an anti-CFTR antibody in $\mathrm{Cftr}^{-/}$and $\mathrm{Cftr}^{+/+}$duodenum showed apical crypt-predominal staining only in the $\mathrm{Cftr}^{+/+}$tissue. Bottom: Apical staining with an antibody against $\beta_{2}$-AR was blocked by preincubation with peptide used to raise the $\beta_{2}$-AR antibody. $\beta_{2}-A R$ antibody stained the apical membrane of crypt as well as villous enterocytes. (B) CFTR and the $\beta_{2}$-AR colocalized in the apical membrane of epithelial cells. In Nherf $1^{-1-}$ mice, the distribution of both proteins appeared more diffuse. Scale bars: $75 \mu \mathrm{m}$ (A); $20 \mu \mathrm{m}$ (B).

villous, such as NHE3, were appropriately enriched in the villous region (data not shown; see Methods for details).

We then assessed the effect of different concentrations of LPA 20:4 in the luminal perfusate on FSK-stimulated duodenal $\mathrm{HCO}_{3}{ }^{-}$ secretion. Based on our findings, $50 \mu \mathrm{M}$ LPA 20:4 was used for all subsequent experiments (see Methods). In WT mice, the simultaneous application of $50 \mu \mathrm{M}$ LPA $20: 4$ with $10^{-4}$ M FSK resulted in a significantly reduced secretory response compared with FSK alone (Figure 7, A and B). In Nherf $2^{-1-}$ mice, no significant difference was seen in the $\mathrm{HCO}_{3}{ }^{-}$stimulatory response to $\mathrm{FSK}$ with and without coapplication of $50 \mu \mathrm{M}$ LPA 20:4 (Figure 7, C and D). The loss of Nherf1 or Pdzk1, on the other hand, did not abolish the inhibitory effect of LPA 20:4 on duodenal $\mathrm{HCO}_{3}{ }^{-}$secretion in vivo (Figure 7E). These results demonstrate an absolute requirement of NHERF2 for $\mathrm{LPA}_{2} \mathrm{R}$-mediated inhibition of CFTR.

Pdzk1 deletion suppresses overall $\mathrm{HCO}_{3}{ }^{-}$secretory rate, but does not interfere with the stimulatory effect of FSK. Pdzk1 deletion resulted in a significant reduction of basal $\mathrm{HCO}_{3}{ }^{-}$secretion, and although this decrease in $\mathrm{HCO}_{3}{ }^{-}$secretory rate remained during FSK stimulation, the relative stimulatory effect of FSK was preserved (Figure 8, A and B). In Pdzk1/-Cftr/- double-deficient mice, very low basal bicarbonate secretion and no significant stimulation of the bicarbonate secretion after FSK perfusion was observed. Surprisingly, the combined deficiency of PDZK1 and NHERF1

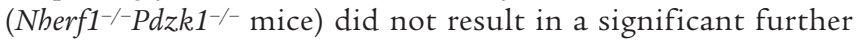
reduction in basal and FSK-stimulated secretion compared with that in Nherf1 $1^{-/-}$mice, and the absence of all 3 NHERF proteins

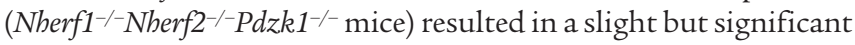
increase in basal and FSK-stimulated $\mathrm{HCO}_{3}{ }^{-}$secretory rate compared with $\mathrm{Nherf1}^{-/-} \mathrm{Pdzk1^{-/- }}$ mice (Figure 8, C and D).

\section{Discussion}

The results of the present study revealed important and differential roles of the NHERF1-NHERF3 proteins in the regulation of CFTR-mediated $\mathrm{HCO}_{3}{ }^{-}$secretion in vivo. The absence of NHERF1 caused a strong reduction in basal $\mathrm{HCO}_{3}{ }^{-}$secretory rate in vivo, 

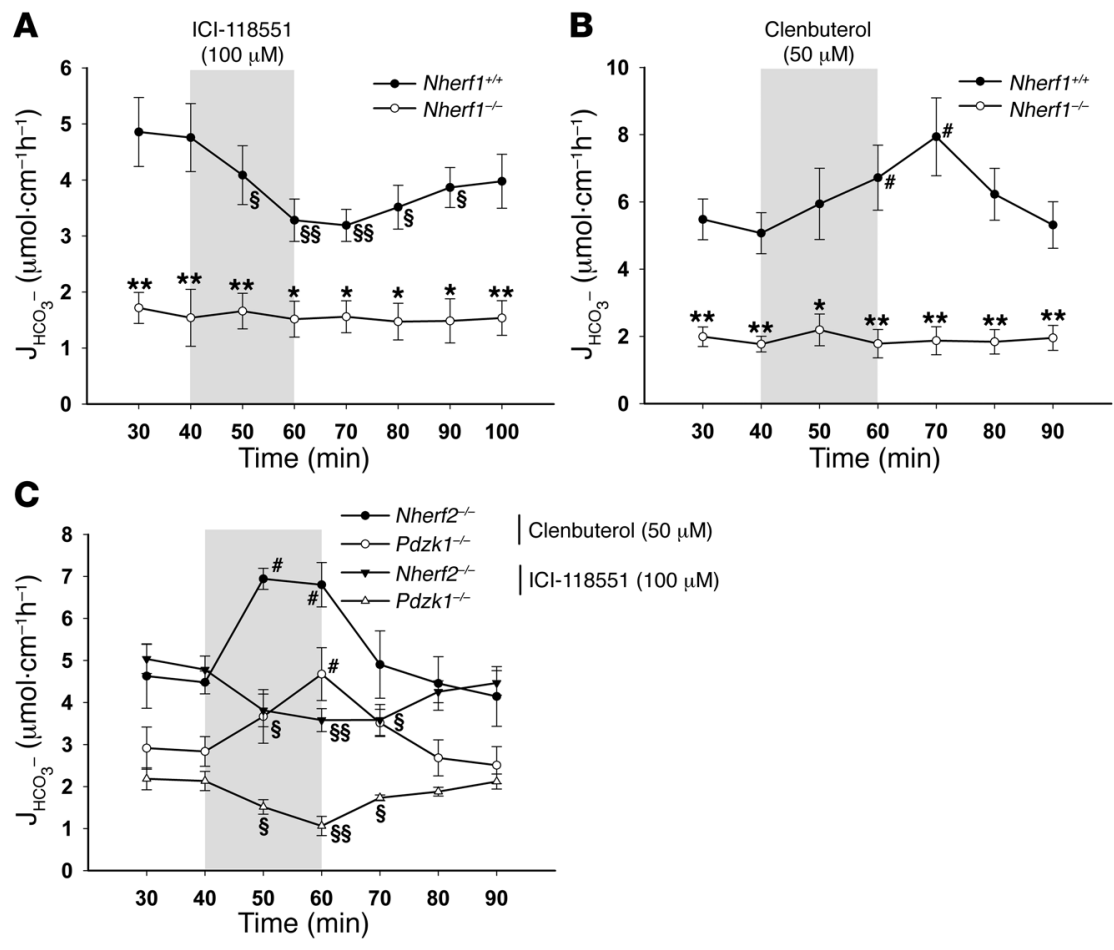

\section{Figure 4}

NHERF1 is essential for $\beta_{2}$-AR-regulated duodenal $\mathrm{HCO}_{3}{ }^{-}$secretion. (A and $\mathbf{B}$ ) The luminal application of $100 \mu \mathrm{M} \mathrm{ICl}-118551$ (see Methods) significantly reduced the basal $\mathrm{HCO}_{3}-$ secretory rate in WT but not Nherf1-/- mice $(n=5)$. (B) Conversely, the luminal application of $50 \mu \mathrm{M}$ clenbuterol (see Methods) significantly stimulated the duodenal $\mathrm{HCO}_{3}{ }^{-}$secretory rate in WT but not Nherf1-- mice $(n=5)$. (C) Both $\mathrm{ICl}-118551$ and clenbuterol had inhibitory and

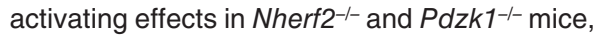
which indicates that the $\beta_{2}$-AR-dependent regulation of CFTR is specific for NHERF1. The 20-min application time is denoted by shading. ${ }^{\star} P<0.01,{ }^{\star \star} P<0.001$ versus WT; $\$ P<0.01$, $\S \S P<0.001$ versus basal value (decrease); $\# P<0.01$ versus basal value (increase). which was not observed in a previous in vitro study (31). Furthermore, the maximal $\mathrm{HCO}_{3}{ }^{-}$secretory rate after $\mathrm{FSK}$ addition was strongly reduced in $\mathrm{Nherf1}^{-/-}$mice, consistent with the previous in vitro findings (31). In addition, a total abrogation of the $\mathrm{HCO}_{3}$ secretory response to the $\beta_{2}$-AR agonist clenbuterol was observed

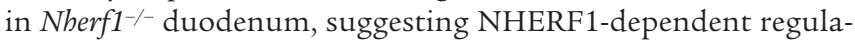
tion of this $G$ protein-coupled receptor in vivo.

The deletion of the structurally similar NHERF2 resulted in a completely different phenotype. The basal duodenal $\mathrm{HCO}_{3}{ }^{-}$secretory rate was slightly, but not significantly, higher than in WT mice, but the FSK-stimulated $\mathrm{HCO}_{3}{ }^{-}$secretory rate was significantly increased. This suggested that NHERF2 exerts an inhibitory effect on intestinal CFTR function. To validate this concept, we studied LPA-mediated inhibition of FSK-stimulated $\mathrm{HCO}_{3}{ }^{-}$secretion and found this inhibition to be absent in Nherf $2^{-/-}$mice. Also, the additional Nherf2 deletion partly rescued the depressed basal $\mathrm{HCO}_{3}{ }^{-}$secretory rate in the Nherf1-/- mice, but augmented the maximal FSK-stimulated rate relatively little, which suggests that NHERF1 and NHERF2 act independently of one another.

$P d z k 1$ ablation caused reduced basal duodenal $\mathrm{HCO}_{3}^{-}$secretion in vivo, but left the relative stimulatory effect of FSK unaffected. Interestingly, Nherf1 $1^{-/-} P d z k 1^{-/-}$mice displayed no significant further reduction in basal or stimulated $\mathrm{HCO}_{3}{ }^{-}$secretion compared with Nherf1 $1^{-/-}$mice, which suggests that PDZK1 may not be able to augment CFTR activity in the absence of NHERF1.

The literature provides ample evidence for a role of the PDZbinding motif of CFTR in the trafficking, membrane retention $(5-7)$, dimerization $(8,9)$, regulation of the lateral mobility in the membrane $(10,11)$, and interaction with other transport proteins (12-14). Most of these studies were performed in cell culture, expressing WT and truncated CFTR and studying the abovenamed functions in a cell-specific setting. Other studies have coexpressed CFTR and one of the NHERF proteins and studied the effect on one of the functions mentioned $(2,3,40,41)$. Cross- linking experiments allowed the isolation and study of multimeric CFTR-containing complexes from native apical membranes (4). The various studies have provided detailed insight into the molecular interactions of CFTR, the NHERF proteins, and other partners in the PDZ adapter-mediated protein complexes. They have, however, provided strong differences in the consequences of disrupting CFTR-NHERF interactions, from a virtually complete trafficking deficit (5) to very mild functional disturbances (6, 7, 42). Whereas some studies suggested an essential role of NHERF proteins for CFTR dimerization $(8,9,43)$, others proposed that CFTR dimers form cAMP dependently, but NHERF independently (4). Thus, the studies of CFTR function in the various NHERFdeficient mice were eagerly awaited.

CFTR functional activity in vivo is assessed by nasal potential difference measurements (44), but these measurements are confounded by the very active $\mathrm{Na}^{+}$conductance in these epithelia (45-47). In the duodenum, CFTR expression is particularly high within the gastrointestinal tract (48), and murine duodenal $\mathrm{HCO}_{3}{ }^{-}$secretion and its agonist-mediated regulation are virtually completely dependent on CFTR expression (33-36). We therefore believe that the measurement of murine duodenal $\mathrm{HCO}_{3}{ }^{-}$secretion may currently be one of the best parameters of studying CFTR regulation in vivo.

Duodenal $\mathrm{HCO}_{3}{ }^{-}$secretion has been studied in the Nherf1-mice in vitro (31). The basal $\mathrm{HCO}_{3}{ }^{-}$secretion and $\mathrm{I}_{\mathrm{sc}}$ were similar to those of WT intestine, but the stimulatory response to cAMP analogs was reduced, corresponding to a reduction of CFTR staining in the apical plasma membrane by approximately $35 \%$ in jejunal crypts (31). The abundance of PDZK1, the absence of which resulted in a decrease of $\mathrm{HCO}_{3}{ }^{-}$secretion and $\mathrm{I}_{\mathrm{sc}}$ in isolated duodenum as well (32), was reduced in enterocytes of $\mathrm{Nherf1}^{-1-}$ mice (31), and it was therefore unclear whether the reduction of $P d z k 1$ in the Nherf $11^{-/-}$jejunum may have been partly responsible for this finding. 
A

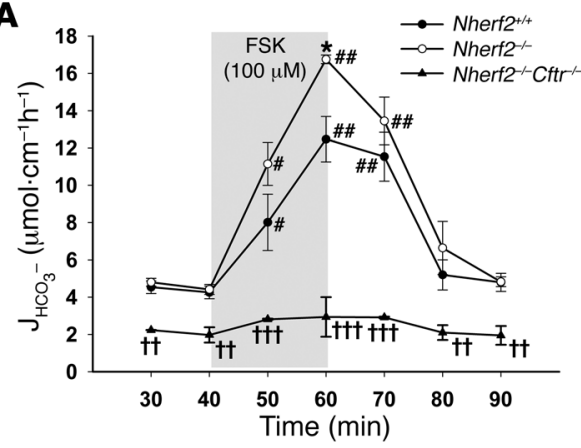

C

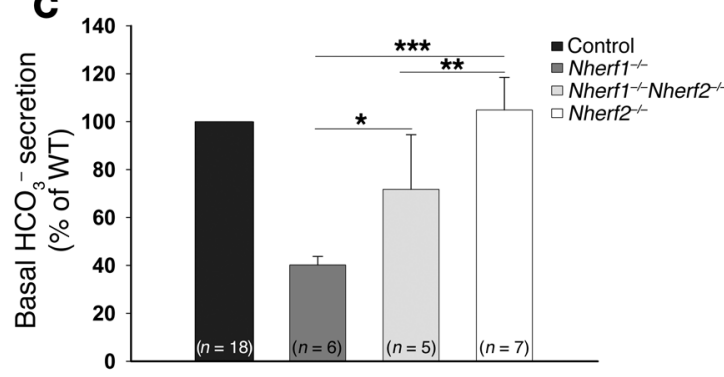

B
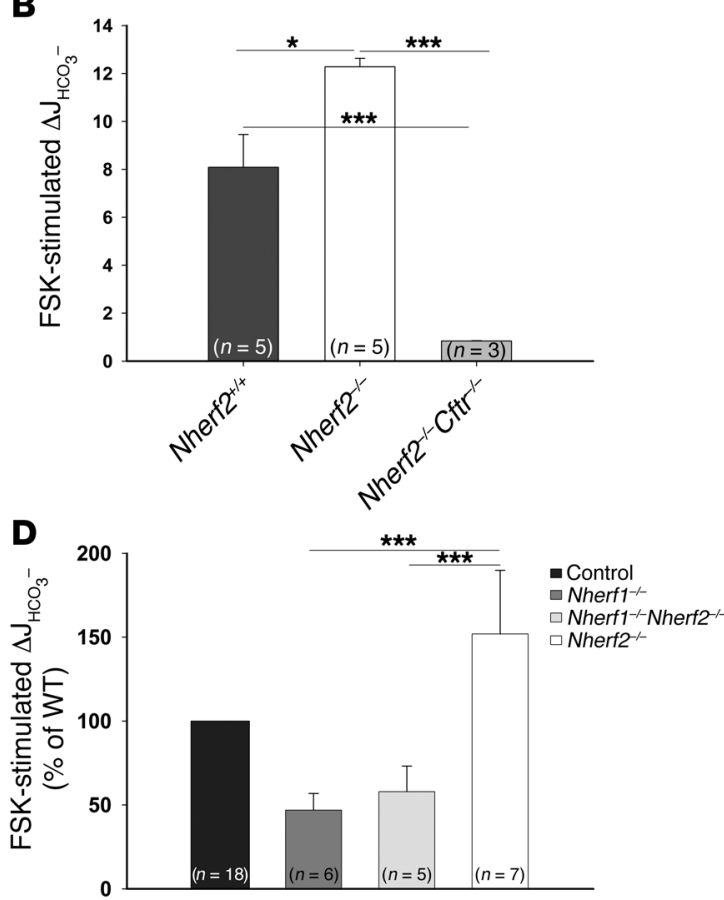

Figure 5

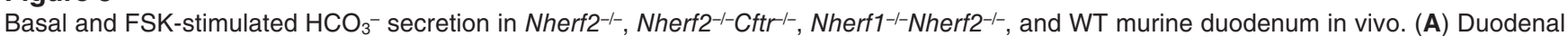
$\mathrm{HCO}_{3}{ }^{-}$secretion was measured as described in Figure 1. The basal $\mathrm{HCO}_{3}{ }^{-}$secretion in Nherf2-- mice was unaltered, whereas the FSK-stimulated duodenal bicarbonate secretion was significantly enhanced compared with WT littermates $(n=5)$. Both basal and FSK-stimulated response were significantly reduced in Nherf2-l-Cftr-- mice $(n=3)$. The 20 -min application time is denoted by shading. ${ }^{*} P<0.05$ versus WT; ${ }^{*} P<0.01$, $\# \#<0.001$ versus basal value; ${ }^{\dagger} P<0.01,{ }^{\dagger+} P<0.001,{ }^{+\dagger+} P<0.0001$ versus $\mathrm{Nherf2}^{-{ }^{-}-}$. (B) The relative increase in $\mathrm{HCO}_{3}{ }^{-}$secretory rate was significantly higher in Nherf2-- mice than in WT littermates (net peak, $P<0.05$ and $P<0.001$ ). (C) The absence of both Nherf1 and Nherf2 resulted in a significantly higher basal $\mathrm{HCO}_{3}{ }^{-}$secretory rate compared with Nherf1 deletion alone, demonstrating that NHERF2 exerts an inhibitory effect independently of NHERF1. (D) Combined Nherf1 and Nherf2 deletion neither worsened nor significantly improved the strongly reduced FSK peak secretory rate observed in Nherf1 ${ }^{--}$mice. (B-D) ${ }^{*} P<0.01$; ${ }^{\star \star} P<0.001$; ${ }^{* \star} P<0.0001$.

We undertook the present in vivo study to assess the role of the 3 structurally similar NHERF proteins in CFTR regulation. In the absence of NHERF1, we found a surprisingly strong reduction of basal $\mathrm{HCO}_{3}{ }^{-}$secretory rate, which was not seen ex vivo in Ussing chamber experiments of isolated duodenal mucosa from the same Nherf1 $1^{-/-}$mouse strain (31). Most likely, the $\mathrm{HCO}_{3}{ }^{-}$secretory rate in vivo is under a considerable secretory tone, and this involves modes of CFTR activation that are NHERF1 dependent. Evidence has been presented that receptor-mediated signaling to CFTR, mediated via the formation of a multiprotein signaling complex, may be lost in the absence of NHERF1. One example, well documented in heterologous expression systems, is the formation of a complex among the $\beta_{2}$-AR, NHERF1, ezrin, PKA, and CFTR that mediates cAMP-dependent, agonist-specific activation of the CFTR current (16). We therefore searched for the presence and potential colocalization of $\beta_{2}$-AR with CFTR in duodenal mucosa as well as for evidence of $\beta_{2}$-AR stimulation of duodenal $\mathrm{HCO}_{3}-$ secretion. Interestingly, the $\beta_{2}$-AR was colocalized with CFTR in the apical membrane of duodenocytes in the crypt region, and the luminal application of the $\beta_{2}$-AR agonist clenbuterol elicited a robust secretory response in WT mice, which was completely abolished in Nherf1 $1^{-/}$duodenum, but present in Nherf2 $2^{-/-}$and $\mathrm{Pdzk1^{-/- }}$ duodenum. In addition, the $\beta_{2}$-AR antagonist ICI- 118551 caused a significant decrease in the basal duodenal $\mathrm{HCO}_{3}{ }^{-}$secretory rate

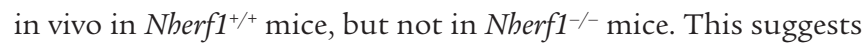
(a) that an activation of $\beta_{2}$-ARs and a $\beta_{2}$-mediated stimulation of bicarbonate secretion are indeed contributing to the basal secretory rate in vivo, and (b) that receptor-mediated CFTR activation can be totally dependent on a specific NHERF isoform, despite the fact that highly homologous PDZ proteins are expressed in the same cells. Interestingly, Adrb2 mRNA expression was significantly upregulated in the duodenum of Nherf1 $1^{-/-}$mice. Little is known about the physiological role of $\beta_{2}$-AR stimulation in the small intestine, but a body of literature exists showing that dopamine and dopamine agonists stimulate duodenal $\mathrm{HCO}_{3}{ }^{-}$secretion (49) and are protective for gastrointestinal mucosa, whereas dopamine antagonists cause duodenal ulceration (50). Recent data demonstrate that dopamine acts in part via binding to $\beta_{2}$-ARs (51), and that not only neural, but also gastrointestinal, epithelial cells can synthesize dopamine, particularly the gastric mucosa (52). Thus, a dopamine release into the luminal fluid, with subsequent access to luminal receptors, is a potential scenario for duodenal mucosal protection and deserves further study.

NHERF2 is highly homologous to NHERF1 (21-25) and has been previously shown to provide the link among CFTR, ezrin, and PKA in airway cells as well as in the A6 kidney cell line $(38,53)$, thereby allowing cAMP stimulation of CFTR. Surprisingly, we found a significantly increased rate of FSK- 
A

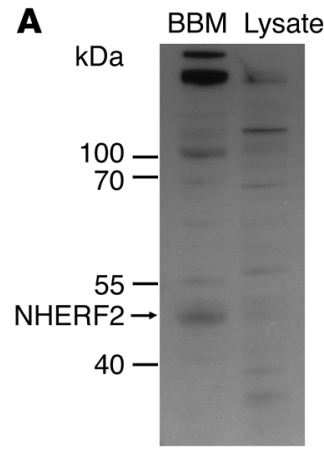

C

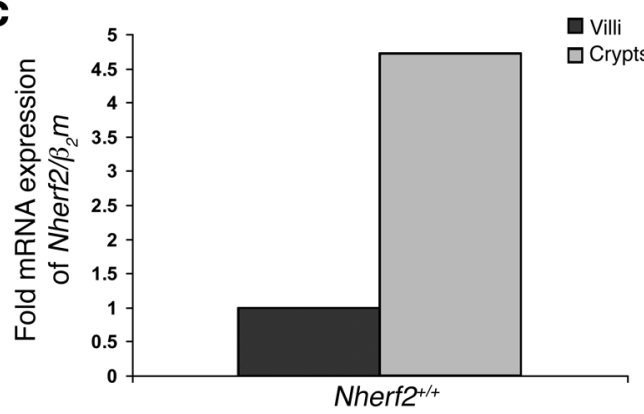

BBM Lysate

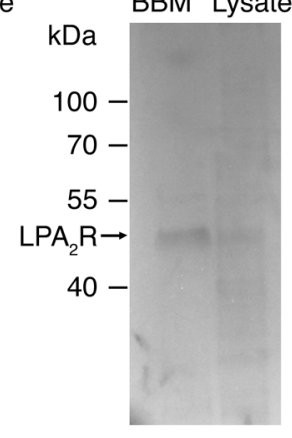

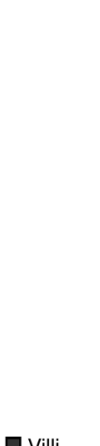

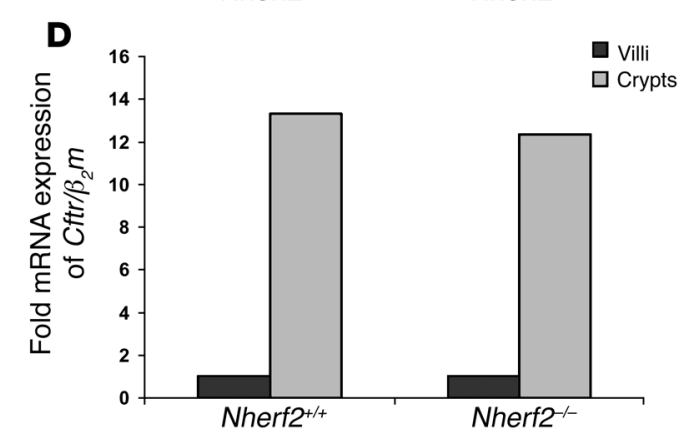

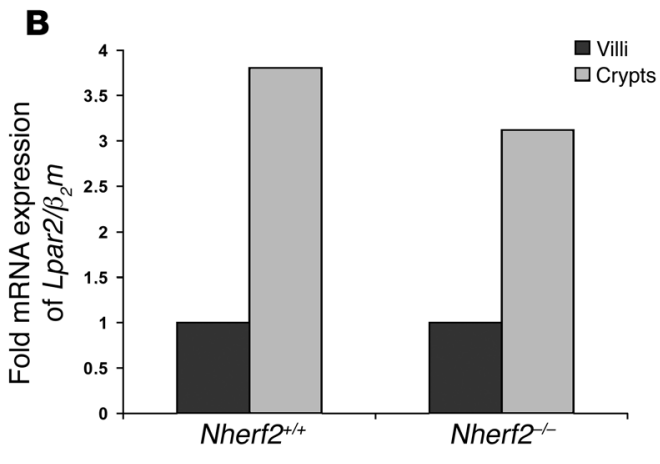

\section{Figure 6}

Duodenal epithelial apical membrane localization of NHERF2 and the LPA 2 R and mRNA expression of Lpar2, Nherf2, and Cftr. (A) Western blot analysis of enriched BBM and duodenal epithelial lysate using antibodies against NHERF2 and LPA $\mathrm{A}_{2}$. Both proteins were enriched in the duodenocyte BBM fraction. The expected molecular weight of the protein is indicated. (B-D) The mRNA expression levels of Lpar2 (B), Nherf2 (C), and Cftr (D) were all markedly higher in the crypt region than in the villous region, indicating coexpression of these 3 proteins in the cryptal region of the duodenum. The Cftr and Lpar2 mRNA expression levels were not significantly different in the Nherf2 $^{-1-}$ mice compared with WT.

stimulated secretory response in Nherf2 $2^{-/-}$compared with WT mice. Obviously, the presence of NHERF2 had some inhibitory effect on CFTR activation by FSK in vivo. To further explore this surprising finding, we generated Nherf1 $1^{-/-} \mathrm{Nherf2^{-/- }}$ mice and compared them with $\mathrm{Nherf1}^{-/-}$mice from the same generation and $N$ herf $1^{+/} N$ herf $2^{+/+}$cousins. The additional Nherf 2 deletion increased the basal $\mathrm{HCO}_{3}{ }^{-}$secretory rate, in line with an inhibitory tone on CFTR conveyed by NHERF2, independent of the presence or absence of NHERF1. Li, Naren, and colleagues provided evidence for the formation of a complex between the apical $\mathrm{LPA}_{2} \mathrm{R}$ and CFTR via NHERF2 in Calu-3 cells and further demonstrated that the administration of LPA 20:4 reduced adenosine-ameliorated $\mathrm{I}_{\mathrm{sc}}$ in chambered mucosa as well as the fluid secretory response to cholera toxin in isolated intestinal loops in vivo (15). We tested various LPA types and concentrations and found them to indeed inhibit maximal FSK-stimulated $\mathrm{HCO}_{3}{ }^{-}$secretory response when administered at the luminal side concomitantly with FSK. Interestingly, this inhibition was completely absent in $\mathrm{Nherf}^{-/-}$mice, but present in $\mathrm{Nherf1}^{-{ }^{-}}$and $P d z k 1^{-1-}$ duodenum, demonstrating the absolute requirement of NHERF2 for LPA-mediated CFTR inhibition. Additional NHERF-mediated regulation of CFTR by G protein-coupled receptors may exist, and may be responsible for the augmented FSK-stimulated $\mathrm{HCO}_{3}{ }^{-}$response in the absence of NHERF2, as well as the increase in basal duodenal $\mathrm{HCO}_{3}{ }^{-}$secretory rate in Nherf1 $1^{-/-}$Nherf $2^{-/-}$mice compared with $\mathrm{Nherf1}^{1^{-/}}$mice.

PDZK1 has previously been shown to augment CFTR dimerization, resulting in an increase in the maximal CFTR current 
A
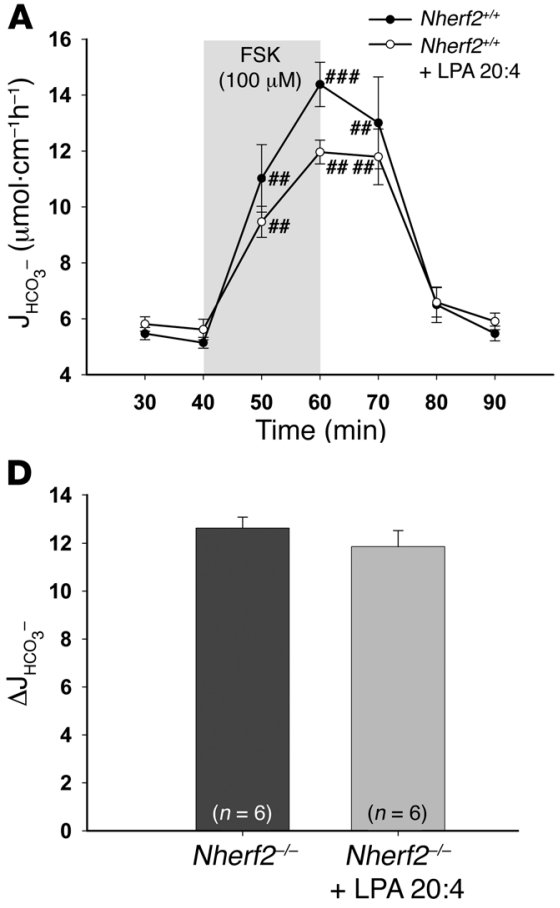

B

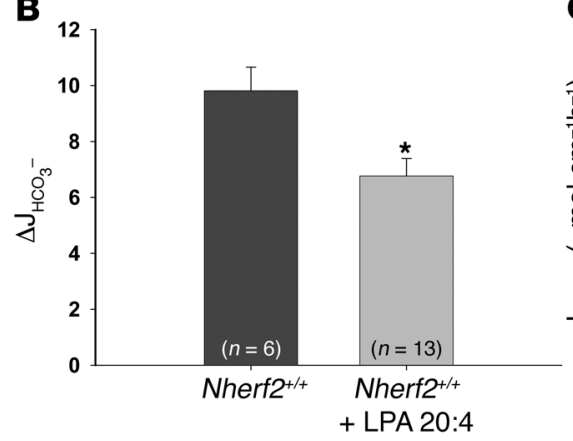

E

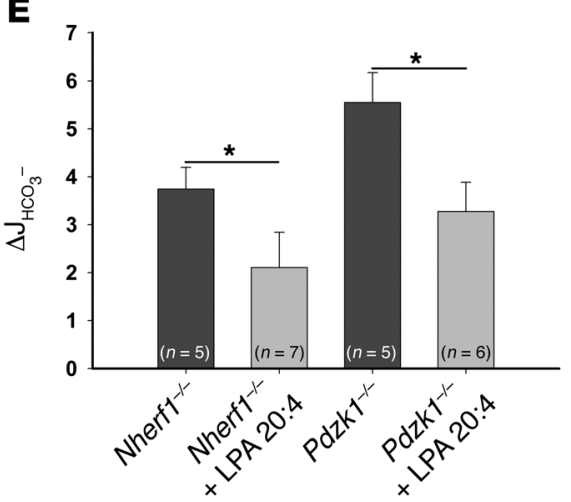

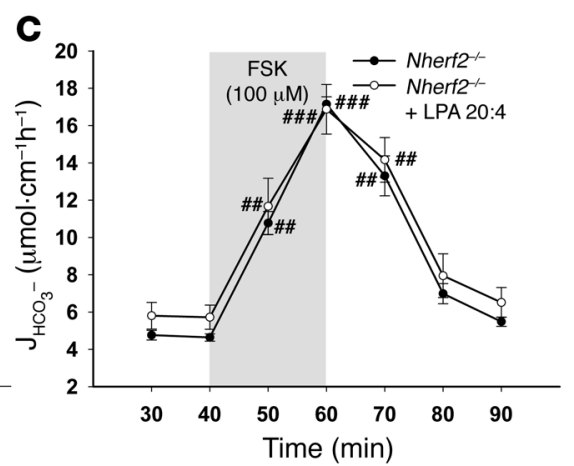

Figure 7

The inhibitory effect of LPA on CFTR-mediated duodenal $\mathrm{HCO}_{3}{ }^{-}$secretion is absent in Nherf2-/- mice. (A-D) LPA 20:4 (50 $\mu$ M), when added simultaneously with $100 \mu \mathrm{M}$ FSK to the luminal perfusate, resulted in significant inhibition of the $\mathrm{FSK}$-stimulated $\mathrm{HCO}_{3}{ }^{-}$secretory response in WT mice (A and $\mathbf{B})$, but not in the Nherf2-/- mice ( $\mathbf{C}$ and $\mathbf{D})$, demonstrating that NHERF2 confers inhibitory signals to CFTR-mediated anion secretion in vivo. In A and C, the 20-min application time is denoted by shading. (E) In contrast, both Nherf1 ${ }^{-/-}$and $P d z k 1^{-/-}$mice showed a significant decrease in the FSK-stimulated duodenal bicarbonate secretion upon coperfusion with $50 \mu \mathrm{M}$ LPA 20:4, indicating that interaction between CFTR and $\mathrm{LPA}_{2} \mathrm{R}$ is NHERF2 specific. ${ }^{*} P<0.05$ versus respective control; ${ }^{P} P<0.01$, \#\# $P<0.001$, \#\#\# $P<0.001$ versus basal value.

alterations of electrolyte transport, and therapeutic interventions targeting individual NHERF proteins may be more effective and specific than previously recognized.

\section{Methods}

Chemicals and solutions. Unless otherwise indicated, reagents were purchased from Calbiochem and Sigma-Aldrich. FSK was diluted in DMSO $\left(10^{-2} \mathrm{M}\right)$, stored at $-20^{\circ} \mathrm{C}$, and added to the $\mathrm{NaCl}$ perfusate to a final concentration of $10^{-4} \mathrm{M}$. LPA 20:4 (Avanti Polar Lipids) was diluted to $0.1 \%(\mathrm{w} / \mathrm{v})$ in PBS ( $\mathrm{pH} 7.2$ ) and added to the $\mathrm{NaCl}$ perfusate to a final concentration of $50 \mu \mathrm{M}$ just before delivery to the duodenum. Clenbuterol and ICI-118551 were purchased from Alexis Biochemicals and diluted in water. Final concentrations in the perfusate were $50 \mu \mathrm{M}$ of clenbuterol and $100 \mu \mathrm{M}$ of ICI-118551.

Animals. All studies were approved by the Hannover Medical School Committee on investigations involving animals and the Regierungspräsidium. All Nherf mutations were congenic for the FVB/N background for at least 15 generations. Age- and sex-matched littermates or cousins were used as controls, and, in the case of double- or triple-KO mice, controls were derived from the same founders. The genotype was determined by PCR. The primer sequences for genotyping Nherf1 mice were as follows: NHERF1 WT forward, TCGGGGTTGTTGGCTGGAGAC; NHERF1 common reverse, AGCCCAACCCGCACTTACCA; NHERF1 mutant forward, AGGGCTGGCACTCTGTCG. Amplicons generated by PCR were 294 bp for the WT gene and $242 \mathrm{bp}$ for the $\mathrm{KO}$ gene. For the Nherf $2^{-/-}$mice (originally generated from Lexicon genetics clone OST2298; ref. 31), the 3 oligonucleotide primers were as follows: E3KARP WT reverse, CCCACCCCCATCGCTGCTC; E3KARP common forward, TTCTATAAGCCTCCATTTCCTCT; and E3KARP mutant reverse, GCGCCAGTCCTCCGATTGA. Amplicons generated by PCR were $303 \mathrm{bp}$ for the WT gene and $229 \mathrm{bp}$ for the KO gene. Pdzk1 mice were genotyped as described previously (29). The mice were housed in a standard animal care room with a 12-h light/12-h dark cycle and were allowed free access to food and water until the start of the experiments.

Surgical procedure and experimental protocol for the measurement of duodenal bicarbonate secretion in vivo. The procedure for the measurement of duodenal $\mathrm{HCO}_{3}{ }^{-}$secretion in vivo has been recently described in detail (36). The concentration of FSK $(100 \mu \mathrm{M})$ was based on the previous report by Hogan et al. (35). The concentration of LPA $(50 \mu \mathrm{M})$ was based on the paper by Li et al. (15), and different concentrations were tested prior to the use of this concentration. The concentrations for specific $\beta_{2}$-AR agonist clenbuterol $(50 \mu \mathrm{M})$ and specific $\beta_{2}$-AR antagonist ICI-118551 (100 $\left.\mu \mathrm{M}\right)$ were taken from the literature (59) and verified experimentally.

Measurement of luminal alkalinization. The rate of luminal alkalinization was determined by back-titration (PHM82 STANDARD pH meter; Radiometer), as previously described (36).

Quantitative real-time PCR. For reverse transcription of RNA, the SuperScript III RNaseH Reverse Transcriptase (Invitrogen) was used. Primers for Adrb2, Villin, and Rps9 as the reference genes were designed with Primer Express (version 2.0; Applied Biosystems) or PRIME (Husar, STZ Genominformatik) software. The sequences for the Adrb2 (encoding $\beta_{2}$-AR; GenBank accession no. NM_007420) were as follows: Adrb2 forward, CTTCCATTGATGTGTTGTGCG; Adrb2 reverse, ATTCTTGGT- 

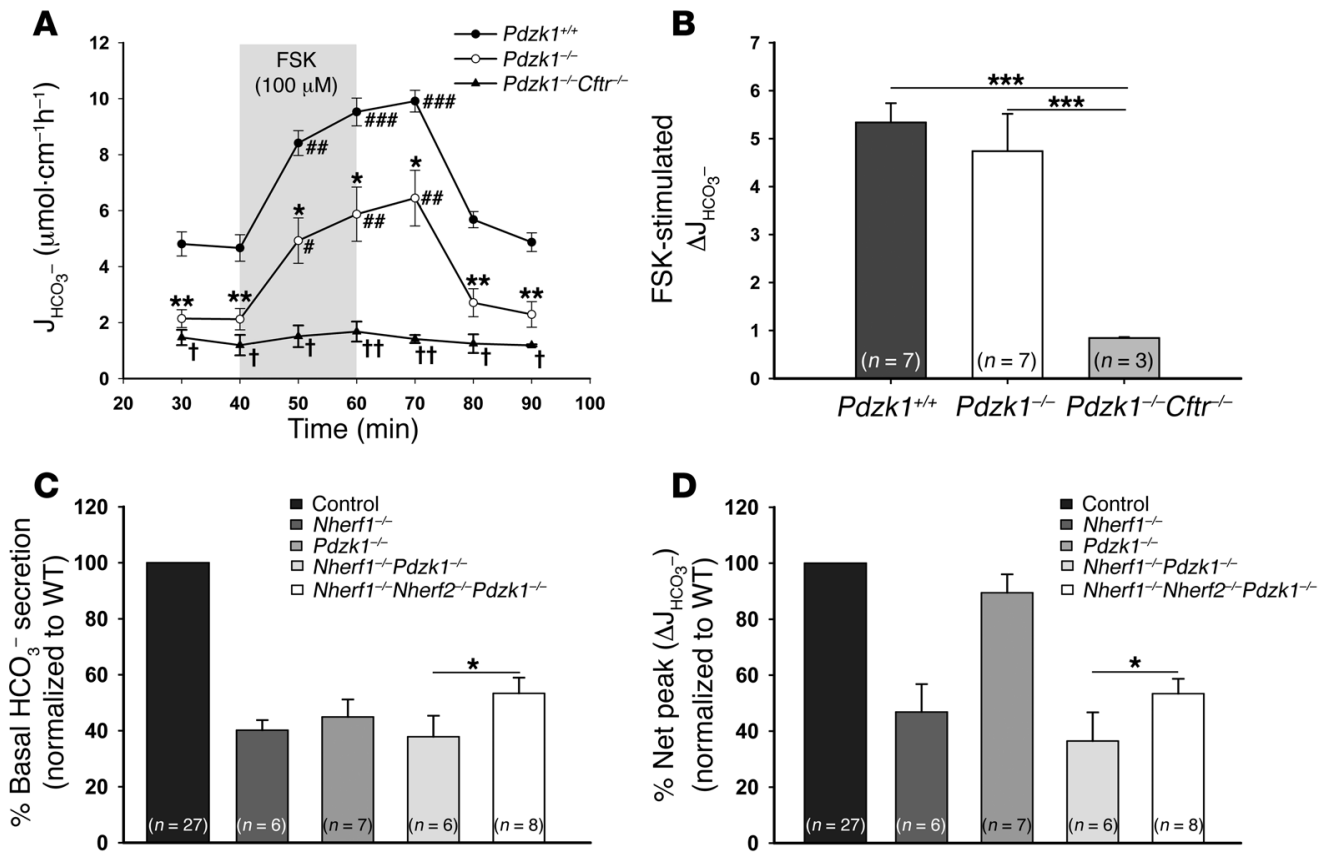

\section{Figure 8}

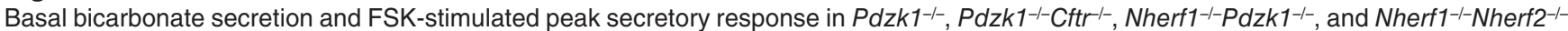
$P d z k 1^{-1-}$ duodenum. (A and B) Basal duodenal $\mathrm{HCO}_{3}{ }^{-}$secretion was significantly reduced in $P d z k 1^{-1-}$ mice compared with WT littermates $(n=7)$. In $\mathbf{A}$, the 20 -min application time is denoted by shading. ${ }^{*} P<0.01,{ }^{* \star} P<0.001$ versus WT; ${ }^{*} P<0.01$, ${ }^{\# \#} P<0.001$, \#\#\# $P<0.001$ versus basal value; ${ }^{\dagger} P<0.01,+\dagger P<0.001$ versus $P d z k 1^{-1-}$. (B) The response to FSK was not altered in $P d z k 1^{-1-}$ mice, but was virtually abolished in $P d z k 1^{-1-}$ $\mathrm{Cftr}^{-1}$ mice. (C) The additional deletion of Nherf2 resulted in a higher basal $\mathrm{HCO}_{3}{ }^{-}$secretory rate than in $\mathrm{Nherf1}^{-/-}$and $\mathrm{Nherf1}^{-1-} \mathrm{Pdzk} 1^{-/-}$mice, congruent with the results in Nherf2-l- and Nherf1-l-Nherf2-l- mice. (D) The defect in FSK stimulation resulting from absence of $\mathrm{Nherf1}^{-1}$ was the

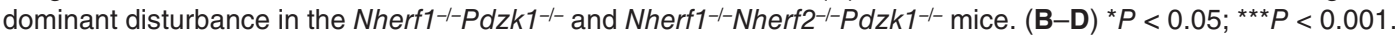

CAGCAGGCTCTG; PCR product, $116 \mathrm{bp}$. The other primers and the PCR procedure have been described previously (60).

Preparation of BBMs. Mouse BBM vesicles from scrapings of duodenal epithelium were prepared as previously described by Hillesheim et al. for the jejunum (32). The duodenum was defined as the first $3 \mathrm{~cm}$ of the small intestine. Duodenal scrapings from 2 mice were pooled per preparation, and the experiments were repeated 3 times. The enriched BBM fraction was assayed for its enrichments factor by performing sucrase and alkaline phosphatase assays as described previously (32).

Western blot analysis. Western blots were prepared as described previously $(32,61)$, with the following modifications. Blots were probed with rat anti-CFTR antibody (3G11 rat monoclonal against mouse CFTR, diluted 1:500; provided by W.E. Balch, Scripps Research Institute, La Jolla, California, USA), rabbit anti-NHERF1 antibody (Ab5199, diluted 1:15,000; provided by C. Yun, Emory University, Atlanta, Georgia, USA), rabbit anti-NHERF2 antibody (Ab2170, diluted 1:5,000; provided by C. Yun), rabbit anti- $\beta_{2}$-AR (diluted 1:200; Santa Cruz Biotechnology Inc.) with and without blocking peptide in TBS-Tween, goat anti-LPA 2 antibody (diluted 1:200; Santa Cruz Biotechnology Inc.) in background reducing buffer (DAKO) overnight at $4^{\circ} \mathrm{C}$. To check the specificity of the staining, the $\beta_{2}-\mathrm{AR}$ and $\mathrm{LPA}_{2} \mathrm{R}$ blocking peptides were used. For CFTR, NHERF1, and NHERF2, tissue from KO mice was used.

Immunofluorescence staining. Duodenum from $\mathrm{Nherf1}^{-/-}$and WT mice was pretreated as described by Cinar et al. (61). Cryosections were treated sequentially with PBS for 5 min, $6 \mathrm{M}$ guanidine ( $\mathrm{pH} 7.0$ ) for $10 \mathrm{~min}$, and washing buffer (PBS with $0.4 \mathrm{M} \mathrm{NaCl}, 0.1 \% \mathrm{BSA}$, and $0.01 \%$ Triton $\times 100$ ) 3 times for $5 \mathrm{~min}$ each. Blocking in $10 \%$ goat serum for $1 \mathrm{~h}$ was followed by incubation overnight with primary antibodies CFTR (as described above, dilut- ed 1:300; provided by W.E. Balch) and affinity-purified rabbit polyclonal $\beta_{2}$-AR (diluted 1:100; Santa Cruz Biotechnology Inc.) at 1:100 in incubation medium (PBS with $3 \%$ goat serum, $3 \% \mathrm{BSA}$, and $0.3 \%$ Triton $\times 100$ ). Washing 4 times for $5 \mathrm{~min}$ in washing buffer was followed by incubation with secondary antibodies (Alexa Fluor 488-labeled goat anti-rat IgG or Alexa Fluor 546-labeled goat anti-rabbit IgG; Invitrogen) for $1 \mathrm{~h}$ at room temperature at a concentration of $2 \mu \mathrm{g} / \mathrm{ml}$ in incubation medium. After 4 washes for $5 \mathrm{~min}$, each cover slide was mounted with SlowFade Gold antifade reagent with DAPI (Invitrogen), and slides were imaged on a confocal microscope (TCS SP2; Leica). Excitation wavelengths used were 405, 488, and $543 \mathrm{~nm}$, and emission was quantitated at 415-450, 490-540, and 560-650 $\mathrm{nm}$ for detection of DAPI, Alexa Fluor 488, and Alexa Fluor 546, respectively.

Laser microdissection and $m R N A$ quantification. For microdissection of crypt and villous duodenocytes from Nherf2 $2^{-/}$and WT mice, cryostat sections were mounted onto MembraneSlides 1.0 PEN (Carl Zeiss) and fixed with $70 \%$ ethanol for $2 \mathrm{~min}$, stained for $3 \mathrm{~min}$ in hematoxylin, immersed in $100 \%$ ethanol, soaked in xylene for $3 \mathrm{~min}$, and air dried. The LaserMicrodissection Microscope (P.A.L.M.) was used to microdissect duodenocytes from the cryptal and the upper villous region (not the tip). Approximately 3,000 microdissected cells per region (crypt versus villi from each duodenum) were picked into RLT buffer, RNA was isolated with RNeasy MicroKit (Qiagen), and reverse transcription was performed as described previously (32). The PCR amplification was performed as described previously (31), but using MESA GREEN qRT-PCR MasterMix Plus instead of SYBR Assay I dTTP (Eurogentec). Primer sequences were as follows: CFTR forward, 5'-TTCTTCACGCCCCTATGTCGA-3'; CFTR reverse, 5'-GCTCCAATCACAATGAACACCA-3'; CFTR PCR product length, 145 bp (GenBank accession no. NM_021050); NHERF2 
forward, 5'-TAGTCGATCCTGAGACTGATG-3', NHERF2 reverse, 5'-ATTGTCCTTCTCTGAGCCTG-3'; NHERF2 PCR product length, 173 bp (GenBank accession no. NM_023449), $\beta_{2}$ m forward, 5'-TGGTGCTTGTCTCACTGACC-3'; $\beta_{2}$ m reverse, 5'-CCGTTCTTCAGCATTTGGAT-3'; $\beta_{2} \mathrm{~m}$ PCR product length, $160 \mathrm{bp}$ (GenBank accession no. NM_009735); $\mathrm{LPA}_{2}$ forward, 5'-AGCCTAGTCAAGACGGTTGTCA-3'; LPA $_{2}$ reverse, 5'-CGTTGCAGGACTTACAGTCCA-3'; LPA 2 PCR product length, $106 \mathrm{bp}$ (GenBank accession no. NM_020028).

Statistics. Descriptive statistics are expressed as mean \pm SEM, with the number of mouse pairs (KO and WT) or individual mice, if applicable, given in parenthesis. Statistical analyses were performed using 2-tailed Student's $t$ test for unpaired data and analysis of variance and Fisher's protected least significant difference for paired data. Results were considered significant at $P<0.05$.

1. Guggino, W.B. 2004. The cystic fibrosis transmembrane regulator forms macromolecular complexes with PDZ domain scaffold proteins. Proc. Am. Thorac. Soc. 1:28-32.

2. Guggino, W., and Stanton, B. 2006. New insights into cystic fibrosis: molecular switches that regulate CFTR. Nat. Rev. Mol. Cell. Biol. 7:426-436.

3. Lamprecht, G., and Seidler, U. 2006. The emerging role of $\mathrm{PDZ}$ adapter proteins for regulation of intestinal ion transport. Am. J. Physiol. Gastrointest. Liver Physiol. 291:G766-G777.

4. Li, C., Roy, K., Dandridge, K., and Naren, A.P. 2004. Molecular assembly of cystic fibrosis transmembrane conductance regulator in plasma membrane. J. Biol. Chem. 279:24673-24684.

5. Moyer, B.D., et al. 1999. A PDZ-interacting domain in CFTR is an apical membrane polarization signal. J. Clin. Invest. 104:1353-1361.

6. Moyer, B.D., et al. 2000. The PDZ-interacting domain of cystic fibrosis transmembrane conductance regulator is required for functional expression in the apical plasma membrane. J. Biol. Chem. 275:27069-27074.

7. Swiatecka-Urban, A., et al. 2002. PDZ domain interaction controls the endocytic recycling of the cystic fibrosis transmembrane conductance regulator. J. Biol. Chem. 277:40099-40105.

8. Raghuram, V., Mak, O.D., and Foskett, J.K. 2001. Regulation of cystic fibrosis transmembrane conductance regulator single-channel gating by bivalent PDZ-domain-mediated interaction. Proc. Natl. Acad. Sci. U. S. A. 98:1300-1305.

9. Wang, S., Yue, H., Derin, R., Guggino, W., and Li, M. 2000. Accessory protein facilitated CFTR-CFTR interaction, a molecular mechanism to potentiate the chloride channel activity. Cell. 103:169-179.

10. Bates, I.R., et al. 2006. Membrane lateral diffusion and capture of CFTR within transient confinement zones. Biophys. J. 91:1046-1058.

11. Haggie, P.M., Stanton, B.A., and Verkman, A.S. 2004. Increased diffusional mobility of CFTR at the plasma membrane after deletion of its C-terminal PDZ binding motif. J. Biol. Chem. 279:5494-5500.

12. Bagorda, A., et al. 2002. Reciprocal protein kinase A regulatory interactions between cystic fibrosis transmembrane conductance regulator and $\mathrm{Na}^{+}$/ $\mathrm{H}+$ exchanger isoform 3 in a renal polarized epithelial cell model. J. Biol. Chem. 277:21480-21488.

13. Ko, S., et al. 2004. Gating of CFTR by the STAS domain of SLC26 transporters. Nat. Cell. Biol. 6:343-350.

14. Li, C., et al. 2007. Spatiotemporal coupling of cAMP transporter to CFTR chloride channel function in the gut epithelia. Cell. 131:940-951.

15. Li, C., et al. 2005. Lysophosphatidic acid inhibits cholera toxin-induced secretory diarrhea through CFTR-dependent protein interactions. J. Exp. Med. 202:975-986.

\section{Acknowledgments}

We thank William E. Balch for providing the $3 \mathrm{G} 11$ rat monoclonal anti-CFTR antibody. This work was funded by DFG grants Se 460 13-4 and SFB621-C9 (to U. Seidler). A.K. Singh was supported by a stipend of the Hannover Biomedical Research School (HBRS).

Received for publication March 6, 2008, and accepted in revised form January 7, 2009.

Address correspondence to: Ursula Seidler, Department of Gastroenterology, Hepatology, and Endocrinology, Hannover Medical School, Carl-Neuberg-Str. 1, 30625 Hannover, Germany. Phone: 49-0-511-532-9427; Fax: 49-0-511-532-8428; E-mail: seidler.ursula@mh-hannover.de.
16. Naren, A.P., et al. 2003. A macromolecular complex of beta 2 adrenergic receptor, CFTR, and ezrin/radixin/moesin-binding phosphoprotein 50 is regulated by PKA. Proc. Natl. Acad. Sci. U. S. A. 100:342-346.

17. Guerra, L., et al. 2005. Na+/H+ exchanger regulatory factor isoform 1 overexpression modulates cystic fibrosis transmembrane conductance regulator (CFTR) expression and activity in human airway 16HBE140- cells and rescues $\{$ delta\}F508 CFTR functional expression in cystic fibrosis cells. J. Biol. Chem. 280:40925-40933.

18. Wolde, M., et al. 2007. Targeting CAL as a negative regulator of $\{$ delta\}F508-CFTR cell-surface expression: an RNA interference and structure-based mutagenetic approach. J. Biol. Chem. 282:8099-8109.

19. Dev, K.K. 2004. Making protein interactions druggable: targeting PDZ domains. Nat. Rev. Drug Discov. 3:1047-1056.

20. Kleizen, B., Braakman, I., and de Jonge, H.R. 2000. Regulated trafficking of the CFTR chloride channel. Eur. J. Cell. Biol. 79:544-556.

21. Donowitz, M., et al. 2005. NHERF family and NHE3 regulation. J. Physiol. 567:3-11.

22. Hernando, N., et al. 2005. NaPi-IIa and interacting partners. J. Physiol. 567:21-26.

23. Lamprecht, G., Weinman, E.J., and Yun, C.H. 1998. The role of NHERF and E3KARP in the cAMP-mediated inhibition of NHE3. J. Biol. Chem. 273:29972-29978.

24. Thelin, W.R., Hodson, C.A., and Milgram, S.L. 2005. Beyond the brush border: NHERF4 blazes new NHERF turf. J. Physiol. 567:13-19.

25. Yun, C.H., Lamprecht, G., Forster, D.V., and Sidor, A. 1998. NHE3 kinase A regulatory protein E3KARP binds the epithelial brush border $\mathrm{Na}+/ \mathrm{H}+$ exchanger NHE3 and the cytoskeletal protein ezrin. J. Biol. Chem. 273:25856-25863.

26. Murtazina, R., et al. 2007. Tissue-specific regulation of sodium/proton exchanger isoform 3 activity in $\mathrm{Na}+/ \mathrm{H}+$ exchanger regulatory factor 1 (NHERF1) null mice: cAMP inhibition is differentially dependent on NHERF1 and exchange protein directly activated by cAMP in ileum versus proximal tubule. J. Biol. Chem. 282:25141-25151.

27. Wade, J.B., et al. 2003. Localization and interaction of NHERF isoforms in the renal proximal tubule of the mouse. Am. J. Physiol. Cell Physiol. 285:C1494-C1503.

28. Wade, J.B., Welling, P.A., Donowitz, M., Shenolikar, S., and Weinman, E.J. 2001. Differential renal distribution of NHERF isoforms and their colocalization with NHE3, ezrin, and ROMK. Am. J. Physiol. Cell Physiol. 280:C192-C198.

29. Kocher, O., Pal, R., Roberts, M., Cirovic, C., and Gilchrist, A. 2003. Targeted disruption of the PDZK1 gene by homologous recombination. Mol. Cell. Biol. 23:1175-1180.
30. Shenolikar, S., Voltz, J.W., Minkoff, C.M., Wade, J.B., and Weinman, E.J. 2002. Targeted disruption of the mouse NHERF-1 gene promotes internalization of proximal tubule sodium-phosphate cotransporter type IIa and renal phosphate wasting. Proc. Natl. Acad. Sci. U. S. A. 99:11470-11475.

31. Broere, N., et al. 2007. Cystic fibrosis transmembrane conductance regulator activation is reduced in the small intestine of $\mathrm{Na}+/ \mathrm{H}+$ exchanger 3 regulatory factor 1 (NHERF-1)- but not NHERF-2-deficient mice. J. Biol. Chem. 282:37575-37584.

32. Hillesheim, J., et al. 2007. Down regulation of small intestinal ion transport in PDZK1(CAP70/NHERF3) deficient mice. Pflugers Arch. 454:575-586.

33. Hogan, D., et al. 1997. Acid-stimulated duodenal bicarbonate secretion involves a CFTR-mediated transport pathway in mice. Gastroenterology. 113:533-541.

34. Seidler, U., et al. 1997. A functional CFTR protein is required for mouse intestinal cAMP-, cGMPand $\mathrm{Ca}(2+)$-dependent HCO3- secretion. J. Physiol. 505:411-423.

35. Hogan, D.L., et al. 1997. CFTR mediates CAMP- and $\mathrm{Ca} 2$--activated duodenal epithelial HCO3-secretion. Am. J. Physiol. 272:G872-G878.

36. Singh, A.K., et al. 2008. CFTR and its key role in in vivo resting and luminal acid-induced duodenal HCO3- secretion. Acta. Physiol. (Oxf.). 193:357-365.

37. Ameen, N., Alexis, J., and Salas, P. 2000. Cellular localization of the cystic fibrosis transmembrane conductance regulator in mouse intestinal tract. Histochem. Cell. Biol. 114:69-75.

38. Sun, F., et al. 2000. E3KARP mediates the association of ezrin and protein kinase A with the cystic fibrosis transmembrane conductance regulator in airway cells. J. Biol. Chem. 275:29539-29546.

39. Hall, R.A., et al. 1998. A C-terminal motif found in the beta(2)-adrenergic receptor, P2Y1 receptor and cystic fibrosis transmembrane conductance regulator determines binding to the $\mathrm{Na}+/ \mathrm{H}+$ exchanger regulatory factor family of PDZ proteins. Proc. Natl. Acad. Sci. U. S. A. 95:8496-8501.

40. Li, C.Y., and Naren, A.P. 2005. Macromolecular complexes of cystic fibrosis transmembrane conductance regulator and its interacting partners. Pharmacol. \& Ther. 108:208-223.

41. Minkoff, C., Shenolikar, S., and Weinman, E.J. 1999. Assembly of signaling complexes by the sodium-hydrogen exchanger regulatory factor family of PDZ-containing proteins. Curr. Opin. Nephrol. Hypertens. 8:603-608.

42. Benharouga, M., et al. 2003. The role of the $\mathrm{C}$ terminus and $\mathrm{Na}^{+} / \mathrm{H}+$ exchanger regulatory factor in the functional expression of cystic fibrosis transmembrane conductance regulator in nonpolarized cells and epithelia. J. Biol. Chem. 278:22079-22089.

43. Li, J.Q., Dai, Z.P., Jana, D., Callaway, D.J.E., and 
Bu, Z.M. 2005. Ezrin controls the macromolecular complexes formed between an adapter protein $\mathrm{Na}+/ \mathrm{H}+$ exchanger regulatory factor and the cystic fibrosis transmembrane conductance regulator. J. Biol. Chem. 280:37634-37643.

44. Knowles, M.R., Paradiso, A.M., and Boucher, R.C. 1995. In-vivo nasal potential difference - techniques and protocols for assessing efficacy of gene-transfer in cystic-fibrosis. Hum. Gene Ther. 6:445-455.

45. Beck, S., et al. 1999. Lack of correlation between CFTR expression, CFTR Cl- currents, amiloride-sensitive $\mathrm{Na}+$ conductance, and cystic fibrosis phenotype. Pediatr. Pulmonol. 27:251-259.

46. Hofmann, T., et al. 1998. Effects of topically delivered benzamil and amiloride on nasal potential difference in cystic fibrosis. Am. J. Respir. Crit. Care. Med. 157:1844-1849.

47. Ruckes-Nilges, C., et al. 1999. Minor role of Clsecretion in non-cystic fibrosis and cystic fibrosis human nasal epithelium. Cell. Physiol. Biochem. 9:1-10

48. Strong, T.V., Boehm, K., and Collins, F.S. 1994 Localization of cystic-fibrosis transmembrane conductance regulator messenger-Rna in the human gastrointestinal-tract by in-situ hybridization. J. Clin. Invest. 93:347-354.

49. Flemstrom, G., Safsten, B., and Jedstedt, G. 1993. Stimulation of mucosal alkaline secretion in rat duodenum by dopamine and dopaminergic compounds. Gastroenterology. 104:825-833.

50. Glavin, G.B., and Szabo, S. 1990. Dopamine in gastrointestinal disease. Dig. Dis. Sci. 35:1153-1161.

51. Zhang, X.H., et al. 2008. beta-Adrenoceptors, but not dopamine receptors, mediate dopamineinduced ion transport in late distal colon of rats. Cell Tissue Res. 334:25-35.

52. Tian, Y.M., et al. 2008. Alteration of dopaminergic markers in gastrointestinal tract of different rodent models of Parkinson's disease. Neuroscience. 153:634-644.

53. Favia, M., et al. 2006. NHE3 inhibits PKA-dependent functional expression of CFTR by NHERF2 PDZ interactions. Biochem. Biophys. Res. Commun. 347:452-459.

54. Zimmermann, C., et al. 2005. Mapping of multidrug resistance gene 1 and multidrug resistanceassociated protein isoform 1 to $5 \mathrm{mRNA}$ expression along the human intestinal tract. Drug Metab. Dispos. 33:219-224.

55. Rossmann, H., et al. 2005. The CFTR associated protein CAP70 interacts with the apical $\mathrm{Cl}-\mathrm{HCO} 3-$ exchanger DRA in rabbit small intestinal mucosa. Biochemistry. 44:4477-4487.

56. Thomson, R.B., et al. 2005. Role of PDZK1 in membrane expression of renal brush border ion exchangers. Proc. Natl. Acad. Sci. U. S. A.
102:13331-13336.

57. Seidler, U., et al. 2008. Sodium and chloride absorptive defects in the small intestine in Slc26a6 null mice. Pflugers. Archiv. 455:757-766.

58. Lamprecht, G., et al. 2002. The down regulated in adenoma (dra) gene product binds to the second PDZ domain of the NHE3 kinase a regulatory protein (E3KARP), potentially linking intestinal Cl-/ $\mathrm{HCO} 3$ - exchange to $\mathrm{Na}+/ \mathrm{H}+$ exchange. Biochemistry. 41:12336-12342.

59. Bakker, A.J., Head, S.I., Wareham, A.C., and Stephenson, D.G. 1998. Effect of clenbuterol on sarcoplasmic reticulum function in single skinned mammalian skeletal muscle fibers. Am. J. Physiol. 274:C1718-C1726.

60. Broere, N., et al. 2008. Defective jejunal and colonic salt absorption and altered $\mathrm{Na}(+) / \mathrm{H}(+)$ exchanger 3 (NHE3) activity in NHE regulatory factor 1 (NHERF1) adaptor protein-deficient mice. Pflugers Arch. doi:10.1007/s00424-008-0579-1.

61. Cinar, A., et al. 2007. NHE3 inhibition by cAMP and $\mathrm{Ca} 2+$ is abolished in PDZ-domain protein PDZK1-deficient murine enterocytes. J. Physiol. 581:1235-1246.

62. Zhu, W.Z., et al. 2005. Heterodimerization of beta1and beta2-adrenergic receptor subtypes optimizes beta-adrenergic modulation of cardiac contractility. Circ. Res. 97:244-251. 